\title{
The Effect of Authentic Leadership, Trust and Work Autonomy Toward Member's Performance of The Indonesian Packaging Federation Association in Jakarta
}

\author{
Raysa Hasyimmi ${ }^{1}$, Farida Elmi ${ }^{2}$ \\ \{rararadiary@gmail.com¹, faridaelmi57@mercubuana.ac.id²\} \\ Mercubuana University, Jakarta, Indonesia ${ }^{12}$
}

\begin{abstract}
This study aims to check the effect of Authentic Leadership, Trust, Work autonomy on employee performance at the Indonesian Packaging Federation Association in Jakarta. The research type is quantitative research with descriptive method. The population of all employees using a nonprobability sampling technique with saturated sampling. This research found 60 respondents as the sample. Analysis using Multiple Linear Regression data in which each variable result has a significant and positive effect, such as Authentic Leadership, Trust, Work Autonomy toward Member Performance. Leadership must give more complete trust to subordinates with work awareness factors for performance to increase the use of performance methods. The results, leadership authentic, trust, Autonomy influential work positive and significant on performance members.
\end{abstract}

Keywords: The Effect Authentic Leadership, Trust, Work Autonomy, Member's Performance

\section{Introduction}

The Indonesian Packaging Federation is a non-profit, non-governmental streamlined business cooperation in Indonesia. The Indonesian Packaging Federation gives each member with Data sharing, Networking, benefits of the business matching, training, workshops, factory visit, seminars, conferences, innovation improvement also Industrial advancement, environment aspects, laws, and regulations. The Indonesian Packaging Federation has a mission to improve packaging quality, technology development, and innovation. There are three levels of Packaging Federation, at the national level is The Indonesian Packaging Federation. Asian level is the Asian Packaging Federation, and the last at the International level is the World Packaging Organization.

The Asian Packaging Federation is a non-profit association established in Tokyo, Japan, in 1967, uniting all corporations around the Asia-Pacific trade and Industry expertise in packaging matter. The aim of the Asian Packaging Federation (APF) is to enhance crossborder cooperation among all packaging-related companies, covering a gamut of subjects such as training, education, development, environmental aspects, laws, and regulations. According to Robbins and Judge (2015: 265), authentic leaders know what they believe is valuable, act on these values, and beliefs openly and frankly. Followers consider them ethical 
people. Based on the results of the interview, the members of the Indonesian Packaging Federation association show that the role of a leader who has the character of Authentic Leadership, Trust, Work autonomy toward member performance is needed the most.

The results of the pre-survey still have some components such as the character of a leader, trust between the leader and subordinates, vice versa, as well as work autonomy that has not been able to achieve optimal performance goals in every national and international event. The increase in members of the Indonesian Packaging Federation association which is influential in developing the leadership character applied gets a percentage of $36 \%$, this shows that the optimization of the Indonesian Packaging Federation internally is still lacking in the component of trust, autonomy which affects member performance. The problems that exist in the Indonesian Packaging Federation association are still lacking with the ability of a leader who is able to provide confidence and work autonomy which has an impact on the performance of the members of the Indonesian Packaging Federation association.

Besides that, the number of members who joined the Indonesian Packaging Federation from 2015 to 2018, in the last 4 years. With the increasing number of members enriching the human resources of the Indonesian Packaging Federation, it can show the development of packaging associations in Indonesia and more information about trends and solutions regarding packaging in Indonesia. In 2019, with the development of this association and increasing members, several surveys and studies were conducted for all members of the Indonesian Packaging Federation Association. The results were obtained by $25 \%$ by monitoring the variables of Authentic Leadership, Trust, and Work Autonomy, to examine how much influence on performance was on all members of the Indonesian Packaging Federation association. Components such as the character of a leader and a leader's trust in his subordinates to achieve optimal performance in members.

The theory for Authentic Leadership is a tool in theoretical research that supported by Avolio (2006) in Haryakusumo (2016: 8) which states authentic leadership is from transformational leadership and ethical leadership, with authentic leaders who can act with certain beliefs to gain credibility and trust from subordinates, and build cooperation with subordinates to achieve optimal performance. In research before as Azhara Alfina Fitri (2018) research shows is a style of Authentic Leadership of significant no effect for employee and the character to Rapid Plast Indonesia,PT. In research Wanki Destriandi (2016) The authentic leadershio variable and trust predictor performance as the members were not significantly and positive influential in the guidance, Jakarta Maritime and Fishery in Kabupaten Kaur.

\section{Research Method}

The research type is quantitative research with descriptive method. The population of all employees using a nonprobability sampling technique with saturated sampling. This research found 60 respondents as the sample. Analysis using Multiple Linear Regression data in which each variable result has a significant and positive effect, such as Authentic Leadership, Trust, Work Autonomy toward Member Performance. Leadership must give more complete trust to subordinates with work awareness factors for performance to increase the use of performance methods. Technique the sample with probability sampling saturated because the population less than 100 so stipulate that the population less than 100 could be saturated, sample so set the sample 60 as respondents. 
The pre-survey results with a high visible percentage, there are still components such as the character of a leader, the trust of a leader in subordinates and vice versa, as well as work autonomy that has not been able to achieve optimal performance goals. The several methods in data collection: interview, with survey of the questionnaire was observation and experimentation. In addition to making interview as the attempt to get primary data in this research also data collection techniques. The data analysis method according to Wijaya (2010: 13) is to determine the validity test used with the validity level of data collection as a questionnaire instrument. According to Priyatno

(2010: 90) in the SPSS (Statistical Package for Social Science) program version 25.0, the testing technique often used for validity testing is to use Product Moment Pearson Correlation, which is the principle of correlating each item's score with the total score obtained in the study. The validity test is carried out to determine whether the items presented in the questionnaire are really able to reveal with certainty what will be studied. The test criteria check by comparing r-Count with r-Table.

\section{Base Decision:}

a. If $r$ count $\geq \mathrm{r}$ table (2-sided test with sig. 0.05 ), the instrument or question items have a significant correlation to the total score or valid.

b. If $\mathrm{r}$ count <table (test 2 with sig. 0.05), the instrument or question items are not significant with the total score or invalid.

Correlation analysis by Priyatno (2010: 16) is used to determine the relationship between the dimensions between independent variables and the dependent variable, also to determine the direction of the relations itself. Measurement of correlation using Product Moment Pearson Correlation with $r$ count $>r$ table and two-sided test, with $\alpha=0.05$. If the significance test results $<0.05$, it can be said that the test results are significant. This study uses SPSS version 25.0 software tools.

\section{Results and Discussion}

Descriptive Analysis Results based on the responses from 60 respondents regarding the research variables. This study will describe in detail the respondent's grouped in descriptive statistics. Delivering an empirical picture of the data used in statistic descriptive research is by using the average value, standard deviation, minimum value, and maximum value. Through this description, it will be known to what extent the respondent's perception of the variables that are indicators in this study.

a. The Validity test result, it can be seen that for the Authentic Leadership variable (X1), consists of ten questions, has a calculated value of $r>r$ table $=0.254$. Thus the Authentic Leadership variable (X1), consists of ten question indicators, is declared valid. The results of the Validity Test of the Authentic Leadership Variable Indicators (X1), from several indicators between them with a result of 0.254 in the $r$ table, it is declared valid, because the requirements are declared valid is with a result of more than 0.254 . Indicators of authentic leadership variables, trust, work autonomy, and performance were declared valid at the Indonesian Packaging Federation Association in Jakarta. 
b. Reliability test result, from the indicators of authentic leadership variables, trust, work autonomy, and performance of all results above 0.6 are declared reliable because the conditions are declared reliable results are above 0.6. Arikunto, (2013) in Rahman Hasibuan (2020).

c. The normality test, aims to test whether in a regression model the dependent variable and the independent variable have a normal distribution or not. A good regression model has a normal distribution, shown by looking at the Normal Probability Plot image. It can be said to be normal if the data points spread around the diagonal line and follow the direction of the diagonal line, Ghazali, (2016: 154).

Table 4.17 Result of Multiple Linier Regression (Y)

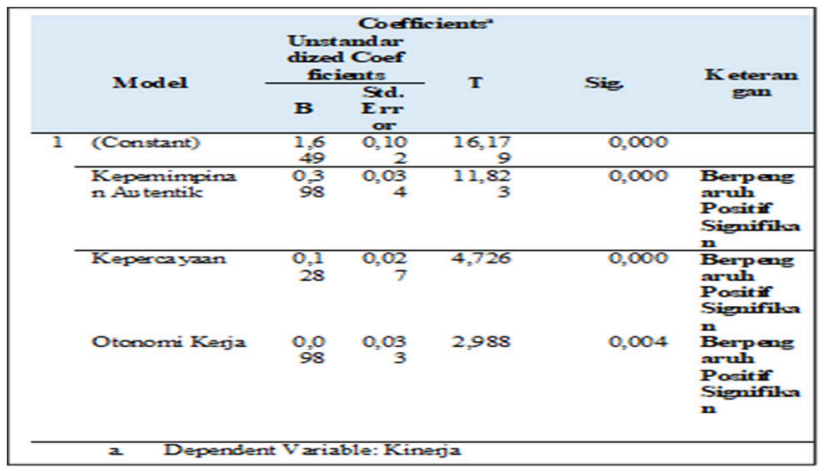

Source: results of analysis using SPSS 25.0 (2020)

- Authentic Leadership (X1) with Performance (Y) has a significant effect with tcount of $11.823(\mathrm{t}$-count $>\mathrm{t}$ table $(\mathrm{df}=56)=2.00)$ and the value of $\mathrm{Sig}=0.000$. The positive coefficient value is 0.398 , indicating that the direction of the relationship between Authentic Leadership (X1) and Performance is positive at 39.8\%. Thus, the H1 hypothesis in this study which states that "Authentic Leadership (X1) has a significant effect on performance (Y)" is accepted.

- Trust (X2) with performance (Y) has a significant effect with t-count of 4.726 (tcount $(\mathrm{df}=56)>2.00)$ and the value of Sig. $=0.000$. The positive coefficient value is 0.128 which indicates that the direction of the relationship between Trust (X2) and Performance is positive at $12.8 \%$. Thus, the research hypothesis $\mathrm{H} 2$ by stating that "Trust (X2) has a significant effect on performance (Y)" is accepted.

- A positive coefficient value of 0.098 can indicate the direction of the relationship between Work Autonomy (X3) and performance is positive at 9.8\%. Thus, the hypothesis H3 with this research can be said that "Work Autonomy (X3) has a significant effect on performance (Y)" is accepted.

- The Inter-Dimensional Correlation Matrix is a statistical analysis that measures the level of the relationship between more than one independent variable (X1, X2, X3) and one dependent variable (Y). Variable correlation analysis is used to determine the relationship between variables both Authentic Leadership (X1), Trust (X2), Work Autonomy (X3), on Performance. Overall data processing and analysis activities are carried out with the help of the SPSS (Statistical Product for Service Solution) software program version 25.0. 
Table 4.18 Results of Dimensional Correlation Matrix

\begin{tabular}{|c|c|c|c|c|}
\hline \multicolumn{5}{|c|}{ Correlations } \\
\hline \multirow[b]{2}{*}{ Variable } & \multirow[b]{2}{*}{ Dimensions } & \multicolumn{3}{|c|}{ Performance (Y) } \\
\hline & & $\begin{array}{l}\text { 4.1 Member } \\
\text { Planning } \\
\text { method of } \\
\text { work }\end{array}$ & $\begin{array}{c}4.2 \text { Use of } \\
\text { Work } \\
\text { Methods } \\
\end{array}$ & $\begin{array}{c}\text { 4.3 Evaluation } \\
\text { of Work } \\
\text { Activities } \\
\end{array}$ \\
\hline \multirow{4}{*}{$\begin{array}{c}\text { Authentic } \\
\text { Leadership (X1) }\end{array}$} & 1.1 Balanced Management & 0,209 & 0,592 & 0,430 \\
\hline & 1.2 Self-Awareness & 0,271 & 0,768 & 0,579 \\
\hline & 1.3 Relationship Transparency & 0,463 & 0,658 & 0,556 \\
\hline & 1.4 Moral perspective & 0,386 & 0,709 & 0,561 \\
\hline \multirow{2}{*}{ Trust (X2) } & 2.1 Beliefs and Beliefs & 0,260 & 0,430 & 0,319 \\
\hline & 2.2 Intention to Believe & 0,371 & 0,478 & 0,371 \\
\hline \multirow[t]{2}{*}{ (X3) } & 3.1 Independence & 0,234 & 0,617 & 0,485 \\
\hline & $\mathrm{N}$ & 60 & 60 & 60 \\
\hline
\end{tabular}

Independence in the work autonomy variable is needed to increase performance $(\mathrm{Y})$, especially in the dimensions of using work methods. The research better, need to increase and expand their respective indicators - variables was used. An appropriate and complete to simplify for the respondents and writer advise to other researcher can do the same study better an addition to using methods and another variable.

\section{Conclusions}

Authentic Leadership Variable has a positive and significant effect on performance, its meaning that the better Authentic Leadership, the performance will also increase. Authentic Leadership Variable is the variable that has the highest influence on performance. The trust variable has a positive and significant effect on performance, its meaning that the better the trust, the performance will also increase. The work autonomy variable has a positive and significant effect on performance, its meaning that the better the work autonomy, the performance will also increase.

Authentic leadership which is owned by a leader must give a sense of trust to the subordinates in any planning work plans or decisions that will be taken by subordinates. The work awareness factor also greatly affects performance and awareness in terms of associations or companies to keep promises, the fairness of the principles of the company, the ability, and skills to increase the use of association performance methods. For better results, it is necessary to add and expand the indicators of each variable used. Suitable and complete indicators can make it easier for respondents to respond. The author suggests further research using variables outside the variables that have been used.

\section{References}

[1] A. D. Hardiani and A. Prasetya, "PENGARUH KEPERCAYAAN ORGANISASIONAL DAN KOMPETENSI TERHADAP KINERJA KARYAWAN MELALUI MOTIVASI KERJA ( Studi Pada Karyawan PT . PLN Persero Distribusi Jawa Barat Area Bekasi ),” J. 
Adm. Bisnis, vol. 61, no. 3, pp. 1-9, 2018, [Online]. Available: administrasibisnis.studentjournal.ub.ac.id\%0A1.

[2] L. Wang, F. Jiang, J. Li, K. Motohashi, and X. Zheng, "The contingent effects of asset specificity, contract specificity, and trust on offshore relationship performance," J. Bus. Res., vol. 99, pp. 338-349, 2019, doi: https://doi.org/10.1016/j.jbusres.2019.02.055.

[3] S. Balkin, D. B., Roussel, P., \& Werner, "Performance contingent pay and autonomy Implications for facilitating extra-role creativity,” Hum. Resour. Manag. Rev., vol. 25, 2015.

[4] B. B. M. and A. B. J. Through, "Improving Organizational Effectiveness Transformational Leadership.” Sage Publications, pp. 42-63., 1990.

[5] Y. L. Chen, H. L., \& Lin, "Goal orientations, leader-leader exchange, trust, and the outcomes of project performance,” Int. J. Proj. Manag., vol. 36(5), pp. 716-729., 2018.

[6] J. Chen et al., "The relationship between team autonomy and new product development performance under different levels of technological turbulence," vol. 80, 2015.

[7] William Job, Authentic Leadership Engagement. 2015.

[8] H. Daryadi, "Pengaruh Kepemimpinan Autentik Dan Partisipasi Guru Dalam Pengambilan Keputusan Terhadap Kinerja Sekolah Dasar Di Kabupaten Sukabumi (Doctoral dissertation, Universitas Pendidikan Indonesia)."

[9] W. De Geyndt, "Does autonomy for public hospitals in developing countries increase performance Evidence-based case studies," Soc. Sci. Med., vol. 179, pp. 74-80., 2017.

[10] F. Elmi, Telisik Manajemen Sumber Daya Manusia. Jakarta Mitra Wacana Media., 2018.

[11] B. George, "True north Discover your authentic leadership," J. Aust., vol. 143, no. 8, pp. 273273, 2010, doi: 10.5694/j.1326-5377.1935.tb43075.x.

[12] A. I. S. Harwita, "PENGARUH OTONOMI TERHADAP KINERJA PEGAWAI DENGAN KEJELASAN TUJUAN ORGANISASI SEBAGAI PEMEDIASI PADA PT. PLN (PERSERO) WILAYAH ACEH,” J. Ilm. Mhs. Ekon. Manaj., vol. 3(3), pp. 59-72., 2018.

[13] M. S. Hasibuan, Manajemen sumber daya manusia. Bumi Aksara., 2016.

[14] R. Hasibuan, "PENGARUH KOMPETENSI KOMUNIKASI, KECERDASAN EMOSIONAL DAN BUDAYA ORGANISASI TERHADAP KINERJA KARYAWAN PADA PT. POS PUSAT BATAM," J. BENING, vol. 7(1), pp. 105-118, 2020.

[15] A. F. Hayuningtyas, D. R. I., \& Helmi, "Peran kepemimpinan otentik terhadap work engagement dosen dengan efikasi diri sebagai mediator. Gadjah Mada Journal of Psychology (GamaJoP)," Gadjah Mada J. Psychol., vol. 1, p. 3, 2015.

[16] M. C. (2017). Hodari, D., Turner, M. J., \& Sturman, "How hotel owner-operator goal congruence and GM autonomy influence hotel performance,” Int. J. Hosp. Manag., vol. 61, pp. 119-128, 2017.

[17] I. Gozali, Aplikasi analisis multivariate dengan program IBM SPSS 19. Semarang Badan Penerbit Universitas Diponegoro, 2011.

[18] P. T. Kotler, Marketing management. Pearson United Kingdom, 2019.

[19] Peter G. Northouse, "Leadership-Theory and Practice. Organization Studies," vol. 20(2), pp. 354-354., 1999.

[20] Y. Lazarova, M., Peretz, H., \& Fried, "Locals know best Subsidiary HR autonomy and subsidiary performance.," J. World Bus., vol. 52, no. 1, pp. 83-96, 2017.

[21] R. D. K. Lubis, "Pengaruh Kepercayaan pada Atasan dan Komitmen Organisasi terhadap Kinerja Karyawan pada Dinas Pendapatan Kota Medan." 2018.

[22] F. Luthans and B. Avolio, "Authentic Leadership Development," 2013.

[23] T. T. Luu, "Linking authentic leadership to salespeople's service performance The roles of job crafting and human resource flexibility.," Ind. Mark. Manag., vol. 84, pp. 89-104, 2020.

[24] A. A. P. Mangkunegara, Manajemen sumber daya manusia perusahaan. PT. Remaja Rosdakarya., 2016.

[25] A. Mangkunegara, A. P., \& Prabu, Evaluasi kinerja sumber daya manusia. Bandung Refika Aditama., 2005.

[26] S. Maysharah, "Pengaruh Kepercayaan dan Teknologi Terhadap Kinerja Operasional dengan Kolaborasi Rantai Pasok Sebagai Variabel Intervening.” 2018. 
[27] C. Dong, X. Yan, R. Tian, Z. Bian, and C. Yao, "Strengthen the process report of clinical trials, promote full transparency of clinical trials," Chinese J. Evidence-Based Med., vol. 18, no. 7, pp. 648-650, 2018, doi: 10.7507/1672-2531.201806071.

[28] and B. K. B. Meng, Juan, "The impact of organizational culture and leadership performance on PR professionals' job satisfaction Testing the joint mediating effects of engagement and trust," Public Relat. Rev.

[29] M. Munizu, "Pengaruh kepercayaan, komitmen, dan teknologi informasi terhadap kinerja Rantai Pasokan (studi kasus ikm Pengolah Buah Markisa di kota Makassar)," J. Manaj. Agribisnis, vol. 14, no. 1, p. 32, 2017.

[30] X. Niu, J., Geng, H., Zhang, Y., \& Du, "Relationship between automation trust and operator performance for the novice and expert in spacecraft rendezvous and docking (RVD)," Appl. Ergon., vol. 71, pp. 1-8, 2018.

[31] and D. F. Pachler, Daniela, Angela Kuonath, "How transformational lecturers promote students' engagement, creativity, and task performance The mediating role of trust in lecturer and self-efficacy."

[32] B. S. Prasetio, A. P., Siregar, S., \& Luturlean, "The effect of the leadership towards employee performance in the human resources department at the PLN west java and banten distribution office," 2015.

[33] G. Przegalinska, A., Ciechanowski, L., Stroz, A., Gloor, P., \& Mazurek, "In bot we trust A new methodology of chatbot performance measures.," Bus. Horiz., vol. 62, no. 6, pp. 785 797, 2019.

[34] T. Robbins, S. P., \& Judge, Essentials of organizational behavior (Vol. 7). Prentice Hall, 2003.

[35] and H. J. Russel, Benardin, "Human Resources Management." 1993.

[36] I. Sanjaya, H. Ghozali, Aplikasi Analisis Multivariete dengan Program IBM SPSS 23 (VIII). Semarang Badan Penerbit Universitas Diponegoro, 2016.

[37] T. W. Sugiyarti, G., \& Meiliana, "Analisis Otonomi Kerja Terhadap Komitmen Organisasi Dan Kepuasan Kerja Dengan Peran Moderasi Budaya Organisasi Pada Pedagang Kaki Lima Di Perumnas Tlogosari Kota Semarang." 2018.

[38] and B. J. A. Walumbwa, Fred O., Peng Wang, Hui Wang, John Schaubroeck, Retracted Psychological processes linking authentic leadership to follower behaviors. 2010.

[39] K. Xu, Q., Fernando, G. D., \& Tam, "Trust and firm performance A bi-directional study. Advances in accounting," Adv. Account., vol. 47, no. 100, p. 433, 2019.

[40] D. Adella, "Pengaruh Kepercayaan Organisasional dan Kompetensi Terhadap Kinerja Karyawan Melalui Motivasi Kerja pada Karyawan PT. PLN Persero," 2018.

[41] S. Arikunto, Prosedur Penelitian Suatu Pendekatan Praktik. PT. Rineka Cipta, 2006. 